\title{
VIIMEISIN MUTTEI VIIMEINEN YHTEISKUNNALLINEN VAIKUTTAMINEN
}

\section{Pääkirjoitus}

\section{of a I U S}

Tämä pääkirjoituksemme on viimeinen JANUKSEN päätoimittajina. Kolmivuotinen toimituskautemme on päättymässä ja lehden toimittaminen siirtyy Itä-Suomen yliopistosta Lapin yliopistoon vuoden 2020 alussa. Samalla koko toimitus vaihtuu. Kiitämme koko toimituksen puolesta saamastamme palautteesta ja kehittämisehdotuksista. Yhteistyö on ollut antoisaa!

Toimituskaudellamme on otettu käyttöön uudistunut OJS3.1-julkaisualusta (Open Journal Systems), jonka kautta artikkeliehdotukset ja refereelausunnot kulkevat. Lisäksi toimitusprosessiin liittyvä kirjeenvaihto ja asiakirjat arkistoituvat järjestelmään. Refereeprosessin etenemistä voivat myös kirjoittajat itse seurata reaaliajassa. Sähköistyneen JANUKSEN lisäksi paperilehti on ilmestynyt rinnalla. Olemme saaneet olla mukana Kotilava-hankkeessa, jossa vauhditetaan avointa julkaisemista, uusineet lehden kotisivut, laatineet kirjoittajien eettiset ohjeet ja kertoneet ajankohtaisista tapahtumista Facebook-yhteisöpalvelussa, jonne olemme tehneet myös "nostoja" julkaistuista teksteistä. Toimituskaudellamme ilmestyy kaksi erikoisnumeroa. Kutsu erikoisnumeron toimittajiksi julkaistiin JANUKSESSA ja tehdyistä ehdotuksista toimitus valitsi kaksi temaattista ehdotusta. Lehden sisällöstä ovat päättäneet erikoisnumeron toimittajat.Vuoden viimeinen lehden numero (4/2019) on erikoisnumero.

Lehden sisältöihin ovat toimituksen lisäksi vaikuttaneet useat eri henkilöt, tärkeimpinä he, jotka tarjoavat artikkelikäsikirjoituksia julkaistavaksi ja he, jotka laativat vertaisarviointeja. Ilahduttavan moni, muukin kuin sosiaalipolitiikan ja sosiaalityön tutkija, on löytänyt julkaisukanavakseen JANUKSEN. Tarjottujen käsikirjoitusten määrä on ollut huikea. Ja useat kymmenet tutkijat ovat suostuneet arvioimaan tieteelliseksi artikkeliksi tarkoitettuja tekstejä. Teille kaikille esitämme lämpimät kiitoksemme huolellisesta ja osaavasta työstänne! Tieteellisessä lehdessä painavin keskustelu käydään tutkimusartikkeleissa, joten osaavien refereiden tekemä työ on ensiarvoisen tärkeää. Palaute käsikirjoituksesta kirjoittajille on voinut harmittavasti viivästyä, joskus liiankin kauan, siksi että lupautuneella vertaisarvioitsijalla on ollut kiire. Myös puheenvuorojen kirjoittajat ja kirja-arvioijat vaikuttavat lehden sisältöön. Puheenvuoroissa kirjoittajat kiinnittävät huomionsa ajankohtaisiin yhteiskunnan kriittisiin pisteisiin, ja kirja-arviot nostavat esiin uusia kirjoja ja niiden herättämiä kysymyksiä. 
JANUKSEN tavoitteena on, että lukijat saisivat eri juttutyyppien avulla mahdollisemman monipuolisen ja laadukkaan lukukokemuksen. Journal.fi-palvelu, jonka kautta sähköistä lehteä voi lukea, mahdollistaa myös JANUKSEN eri juttujen latausmäärien seurannan. JANUKSESSA julkaistut tekstit tavoittavat lukijoita hyvin ja lukijakunnan määä näyttää nousujohtoiselta jokaisessa juttutyypissä. JANUKSESSA julkaistu teksti on ollut useamman kerran journal.fi -palvelussa viiden eniten ladatun joukossa.

Tiedelehdessä julkaiseminen on yksi tapa vaikuttaa ja osallistua yhteiskunnalliseen keskusteluun. Näinä "mittaroinnin" aikoina tieteen vaikuttavuutta arvioidaan laskemalla artikkeleihin viittaamisen määrää ja luomalla tiedelehdille laatuluokituksia. Myös tutkijoiden "näkyvyyttä" yritetään määällistää ja mitata. Yliopistojen yksi keskeinen tehtävä onkin osallistua yhteiskunnalliseen vaikuttamiseen ja yliopistolaiset vaikuttavat yhteiskuntaan useilla eri foorumeilla ja tavoilla. Tutkijoita rohkaistaan välittämään tutkittua tietoa ja puhumaan toimittajille osana tutkimustoimintaansa. Sanomalehdet, radio, televisio ja sosiaalinen media tavoittavat yleensä paljon suuremman yleisön kuin tiedejulkaisu. Toimittajat kuitenkin harmittelevat usein, että tutkijoita on hankala saada lähtemään mukaan julkiseen keskusteluun. Syitä on monia.

Journalistinen haastattelu voi olla toimittajalle pelkästään tiedonhankintakeino, jolloin tutkijan osallistuminen siihen ei näy lehtiartikkelissa tai siteerattavaksi valittu tekstiaines irrotetaan haastattelusta ja istutetaan valittuun kohtaan lehtijuttuun sopivaksi. Suorat lainaukset haastateltavan puheesta eivät ole välttämättä sitä, mitä on puhuttu. Sitaatit ikään kuin vahvistavat tuntua haastateltavan läsnäolosta. (Haapanen 2017.) Ristiriitaista, mutta siteeraaminen ei ole yksinkertaista. Usein lehtijutut perustuvat useilta haastateltavilta saatuihin tietoihin, joista osa merkitään haastateltavan lainaamiseksi ja ehkä suurin osa toimittajan omaksi kerronnaksi leipätekstiin.Tämä saattaa hämmentää ja yllättää haastattelun antajia ja myös lukijoita.

Yksittäisen tutkijan aikapaineet, varovaisuus ja ehkä pettymyskin estävät tai mietityttävät journalistiseen haastatteluun osallistumista. Eritoten kun journalistiseen haastatteluun liittyvät myös tiukat aikataulut ja "deadlinet". Kansallisissa tutkimuksissa (Tiitinen 2018) on todettu, että sosiaalityö vetäytyy julkisuudesta ja alalla vallitsee hiljaisuuden ja varovaisen viestinnän kulttuuri. Julkinen keskustelu antaa sosiaalityöstä tehottoman, epäonnistuneen ja valtaa ylikäyttävän kuvan, vaikka sosiaalityöntekijöitä ei aina syytettäisikään kyseessä olevasta tilanteesta.Vaikenemista ei tietenkään saisi ottaa vaihtoehdoksi, vaan ryhtyä kollektiivisiin toimiin aggressiivisen palautteen hävittämiseksi.Tällaisen kanssa ovat useiden vuosien ajan olleet vaikeuksissa erityisesti monikulttuurisuuden, mahanmuuton, lastensuojelun ja ilmastomuutoksen tutkijat.

Journalistisen haastattelun päätavoitteet ovat hyvä juttu ja tiedonvälitys. Tutkijoiden näkökulmasta tutkimustuloksista tiedottaminen, tieteen popularisointi ja ajankohtaisten yhteiskunnallisten asioiden kommentointi ovat tärkeä osa tiedeviestintää. 
Yhteiskunnallista keskustelua on vaikea tiivistää muutamaan houkuttelevaan virkkeeseen saatikka koukuttavaan otsikkoon. Kipukohtia on molemmin puolin.

Kiitämme JANUKSEN toimituskumppaneita ja toimitusneuvostoa hyvin sujuneesta ja antoisasta yhteistyöstä! Toivomme uudelle JANUKSEN toimitukselle Lapin yliopistoon innostavia lehden toimitusvuosia ja rohkeita kehittämisideoita, jotta tiedelehtemme palvelisi vieläkin paremmin kirjoittajiamme ja lukijoitamme!

Tässä Januksessa ilmestyy neljä artikkelia. Päivi Ahosola ja Kirsi Lumme-Sandt tutkivat, millaisia ovat vanhuspalveluiden kehittämishankkeet ja kuinka ne jakavat vastuuta vanhuspalvelujärjestelmän sisällä eri toimijoiden kesken. Päivi Mäntyneva ja Anna-Maria Isola tarkastelevat kuntouttavan työtoiminnan mielekkyyttä pitkäaikaistyöttömien elämän kohentamisessa. Aino Rekola ja Riikka Paloniemi analysoivat kaupunkisuunnittelijoiden käsityksiä oikeudenmukaisuudesta. Ilmari Rostila pohtii objektiivista hermeneutiikkaa tapaustutkimuksen - tässä sosiaalityöntekijän toiminnan - lähestymistapana.

Antoisia lukuhetkiä!

Eeva Jokinen ja Aini Pehkonen

\section{KirJallisuUs}

Haapanen, Lauri (2017) Quoting Practices in written journalism. Helsinki: Helsingin yliopisto. http://heda.helsinki.fi/handle/10138/174618

Tiitinen, Laura (2018) Kamppailu sananvapaudesta: sosiaalialan ammattilaisen toiminta ja valtasuhteet mediavaikuttamisen kentällä. Rovaniemi: Lapin yliopisto. http://urn.fi/ URN:ISBN:978-952-337-147-7 